\title{
Gene Expression of Mouse Hippocampal Stem Cells Grown in a Galactose-Derived Molecular Gel Compared to In Vivo and Neurospheres
}

\author{
Keziban Korkmaz Bayram 1,2,3,*, Juliette Fitremann ${ }^{4}$, Arslan Bayram ${ }^{5} \mathbb{D}$, Zeynep Y1lmaz ${ }^{2,6}$, \\ Ecmel Mehmetbeyoğlu ${ }^{2}$ (D), Yusuf Özkul ${ }^{2,7}$ and Minoo Rassoulzadegan ${ }^{2,8}$
}

Citation: Bayram, K.K.; Fitremann, J.; Bayram, A.; Yılmaz, Z.;

Mehmetbeyoğlu, E.; Özkul, Y.;

Rassoulzadegan, M. Gene Expression

of Mouse Hippocampal Stem Cells

Grown in a Galactose-Derived

Molecular Gel Compared to In Vivo and Neurospheres. Processes 2021, 9 , 716. https://doi.org/10.3390/ pr9040716

Academic Editor:

Shreyas Kuddannaya

Received: 5 March 2021

Accepted: 13 April 2021

Published: 18 April 2021

Publisher's Note: MDPI stays neutral with regard to jurisdictional claims in published maps and institutional affiliations.

Copyright: (c) 2021 by the authors Licensee MDPI, Basel, Switzerland. This article is an open access article distributed under the terms and conditions of the Creative Commons Attribution (CC BY) license (https:/ / creativecommons.org/licenses/by/ $4.0 /)$.
1 Department of Medical Genetics, Medical Faculty, Ankara Yıldırım Beyazıt University, 06800 Ankara, Turkey

2 Genome and Stem Cell Center (GENKOK), Erciyes University, 38039 Kayseri, Turkey; zeynepyilmaz_55@hotmail.com (Z.Y.); mehmetbeyogluse@cardiff.ac.uk (E.M.); ozkul@erciyes.edu.tr (Y.Ö.); minoo.rassoulzadegan@unice.fr (M.R.)

3 "Central Research Laboratory" Research and Application Center, Ankara Yıldırım Beyazıt University, 06010 Ankara, Turkey

4 Laboratoire des IMRCP, Université de Toulouse, CNRS UMR 5623, Université Toulouse III-Paul Sabatier, 31062 Toulouse, France; fitreman@chimie.ups-tlse.fr

5 Medical Genetics Department of Etlik Zubeyde Hanım Women's Diseases Education and Research Hospital, 06010 Ankara, Turkey; dr.arslan.b@gmail.com

6 Department of Medical Biology, Medical Faculty, Erciyes University, 38039 Kayseri, Turkey

7 Department of Medical Genetics, Medical Faculty, Erciyes University, 38039 Kayseri, Turkey

8 University of Nice, Inserm, CNRS, 06000 Nice, France

* Correspondence: kkorkmazbayram@ybu.edu.tr; Tel.: +90-312-9062-492

\begin{abstract}
Background: N-heptyl-D-galactonamide (GalC7) is a small synthetic carbohydrate derivative that forms a biocompatible supramolecular hydrogel. In this study, the objective was to analyze more in-depth how neural cells differentiate in contact with GalC7. Method: Direct (ex vivo) cells of the fresh hippocampus and culture (In vitro) of the primary cells were investigated. In vitro, investigation performed under three conditions: on culture in neurospheres for 19 days, on culture in GalC7 gel for 7 days, and on culture in both neurospheres and GalC7 gel. Total RNA was isolated with TRIzol from each group, Sox8, Sox 9 , Sox10, Dcx, and Neurod1 expression levels were measured by qPCR. Result: Sox 8 and Sox10, oligodendrocyte markers, and Sox9, an astrocyte marker, were expressed at a much higher level after 7 days of culture in GalC7 hydrogel compared to all other conditions. Dcx, a marker of neurogenesis, and Neurod1, a marker of neuronal differentiation, were expressed at better levels in the GalC7 gel culture compared to the neurosphere. Conclusions: These results show that the GalC7 hydrogel brings different and interesting conditions for inducing the differentiation and maturation of neural progenitor cells compared with polymer-based scaffolds or cell-only conditions. The differences observed open new perspectives in tissue engineering, induction, and transcript analysis.
\end{abstract}

Keywords: self-assembly; low molecular weight hydrogel; galactolipid; neurosphere; neuron; 3D cell culture; hippocampus; mRNA expression; qPCR

\section{Introduction}

In vitro conditions that reproduce in vivo profile of gene expression is a critical foundation of cell culture. Frustration in this area is high and there is a growing concern for research in particular, given the impact of working on living organisms and on the understanding of the mechanisms involved. Cell culture often reproduces the criteria required very incompletely. However, this approach has obvious practical and financial advantages and has often led to discoveries. Given the complexity of biological research, especially in neuroscience the challenge is topical to find the better conditions in experimental methods 
to reveal all aspects of cell complexities. For example, the use of cell culture often leads to stages of differentiation that differ compared to in vivo. Likewise, culture conditions have been shown to produce significant variability.

Currently, new biomaterials are being developed for 3D cell culture techniques to allow the growth and differentiation of neuronal cells. Researchers' greatest expectation for biomaterials is that they can better mimic in vivo behavior. Primary cells, although more difficult to grow than cell lines, exhibit a behavior that is more like cells in vivo. Thus, developing in vitro 3D models starting from primary cells, is likely to provide more relevant results, closer to what is observed in vivo [1-4]. This approach is important notably for gaining a better understanding of the differentiation or interactions between cells or the effect of drugs and so on, in more relevant conditions.

In the case of the central nervous system (CNS), extracts from some specific regions of the brain, notably hippocampus and more especially, embryo hippocampus, contain a high number of neural stem cells and neural progenitor cells. Neurosphere assays have proven to be an efficient method to isolate neural progenitor cells from different parts of the embryonic or adult brain. In neurosphere culture conditions, these cells keep their ability of self-renewal in vitro and upon induction, they can differentiate into neurons, astrocytes, and oligodendrocytes. Therefore, neurospheres are useful in vitro models for mimicking the diversity of cells observed in vivo and their interactions in 3D conditions. Different methods have been described for obtaining neurospheres and the use of this 3D model for different purposes has been discussed [4-6]. Other 3D models relying only on cell self-organization are brain organoids, but growing organoids is more complex compared with neurospheres $[7,8]$.

Alternatives to cell-only 3D models introduce scaffolds made of biomaterials, which intend to mimic the extracellular matrix function. The interactions between the cells and the scaffold strongly affect the cell proliferation, 3D distribution in space, differentiation, cell-cell interactions, and so on. Hence the scaffold cannot be considered just as a neutral support for the cell growth in 3D. Highlighting the impact of the scaffold on the gene expression of the cultivated cells is thus very important in order to better select the right scaffold for a given application $[9,10]$. Many biomaterials of different types are currently being developed for addressing in vitro 3D cell cultures of neuronal cells. They are most often derived from the extracellular matrix (ECM) or its components [9-11] or made of bio sourced polymers [9,12-14] and purely synthetic [15] or bio sourced/synthetic composites [11,16]. Emerging alternative biomaterials for neuron cell culture are selfassembling fibrillar scaffolds [17-26]. In these materials, the formation of the gel is not based on a polymer network but results from the self-assembly of small molecules of low molecular weight through non-covalent interactions into a "self-assembling fibrillar network" (SAFIN). Interestingly, these gels are very soft at the macroscopic and microscopic scale, which is favorable to the growth and differentiation into neurons $[20,27,28]$. Secondly, they form fibers with very various sizes, morphology, and local stiffness that are gelatorspecific and may provide original mechanical, geometrical, and topographical cues for cells. In particular, it has been shown that the morphology of the fibers at the nanoscale, including helix chirality or nanogrooves impacts the cell behavior $[20,29,30]$. In the case of neurons, the differentiation of a neurite into an axon or dendrite depends on the rigidity of the substrate [28], and the path taken by a neurite depends on mechanical signals [31]. Mechanical and topological signals may be quite original in the case of molecular hydrogel scaffolds and may induce significant differences in neural cell cultures.

The objective of this work was to explore the difference in cell expression profile of primary cells extracted from the hippocampi of mouse embryo brains, in four different conditions (Figure 1): (1) in vivo at day 19.5 pc; (2) grown in N-heptyl-Dgalactonamide supramolecular hydrogel (GalC7) for 7 days; (3) grown in neurospheres (pHEMA) for 19 days; and (4) grown in neurospheres (pHEMA) for 12 days then in N-heptyl-D-galactonamide supramolecular hydrogel (GalC7) for 7 days. The neurospheres are formed in non-adhesive conditions, in culture plates coated with poly(2- 
hydroxymethacrylate). N-heptyl-D-galactonamide is a synthetic carbohydrate-based low molecular weight gelator that self-assemble in a network of wide ribbons supporting the supramolecular hydrogel (Figure 2). Since it is a small synthetic molecule and not a polymer, it is not submitted to batches variations. Therefore, more reproducible conditions for cell culture are expected. In a previous study, it has been shown that N-heptyl-Dgalactonamide supramolecular hydrogel is suitable for the growth and differentiation of adult human neural stem cell (hNSC) in 3D [20]. Additionally, 3D constructs can be made by $3 \mathrm{D}$ printing $[32,33]$. However, this hydrogel is nearly completely consumed by the cells after 7 days. For this reason, we introduced in the study design the condition (4) in which a 19-days old culture is performed, but with the final 7 days carried out on the GalC7 hydrogel. Thus, the conditions (3) and (4) will highlight how the abundance of neural progenitor cells is affected by early-stage cell culture conditions and also how the GalC7 hydrogel can change the response of a 12 days neurosphere culture.

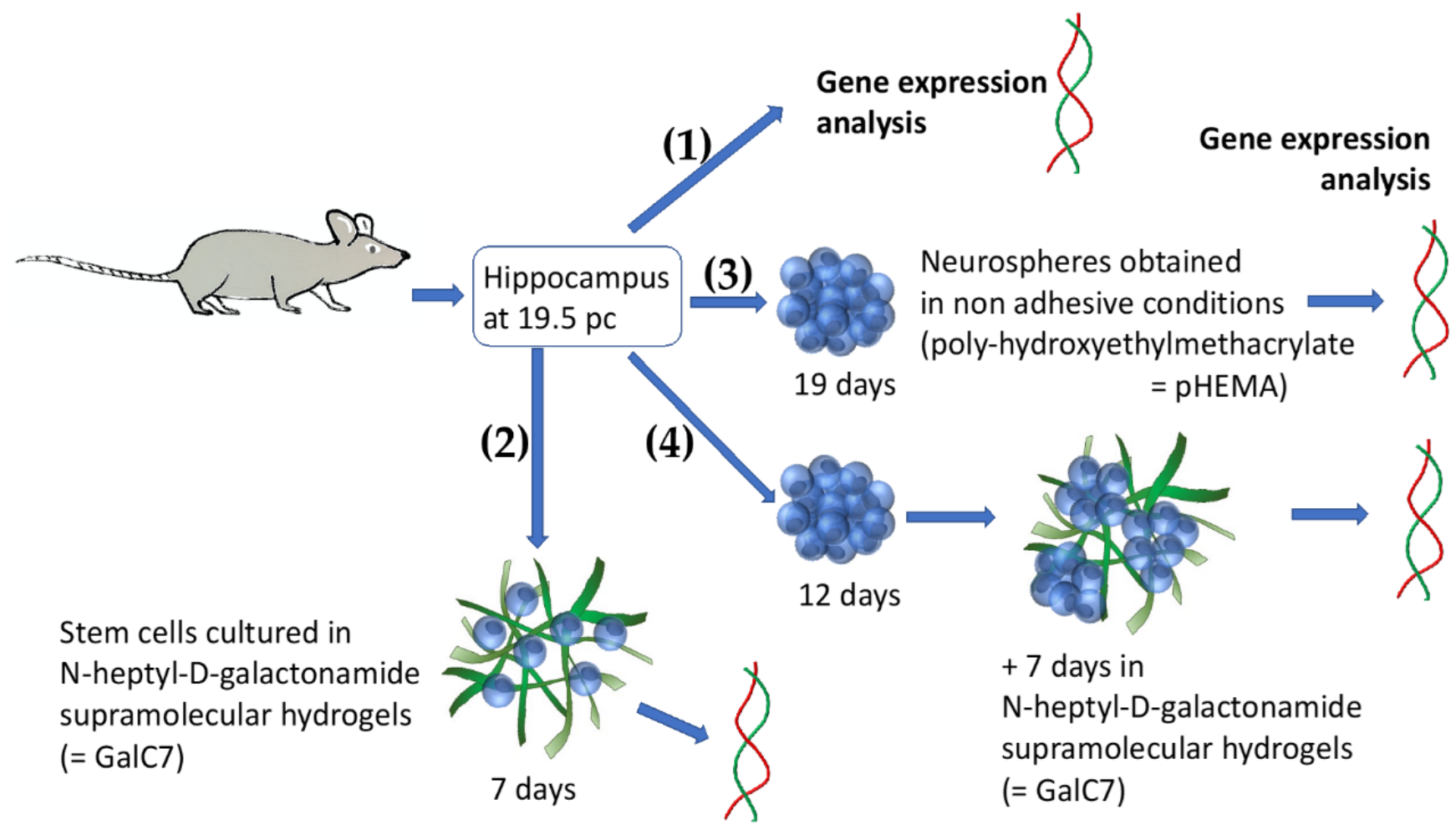

Figure 1. Study design: four conditions for the cell culture of mouse embryo hippocampi primary cells followed by gene expression analysis by qPCR. (1) in vivo at day 19.5 pc; (2) grown in N-heptyl-D-galactonamide supramolecular hydrogel (GalC7) for 7 days; (3) grown in neurospheres (pHEMA) for 19 days; and (4) grown in neurospheres (pHEMA) for 12 days then in N-heptyl-D-galactonamide supramolecular hydrogel (GalC7) for 7 days. 
(a)<smiles>CCCCCCCNC(=O)[C@@H](O)[C@H](O)[C@H](O)[C@H](O)CO</smiles>

\section{N-heptyl-D-galactonamide (GalC7) $=$}

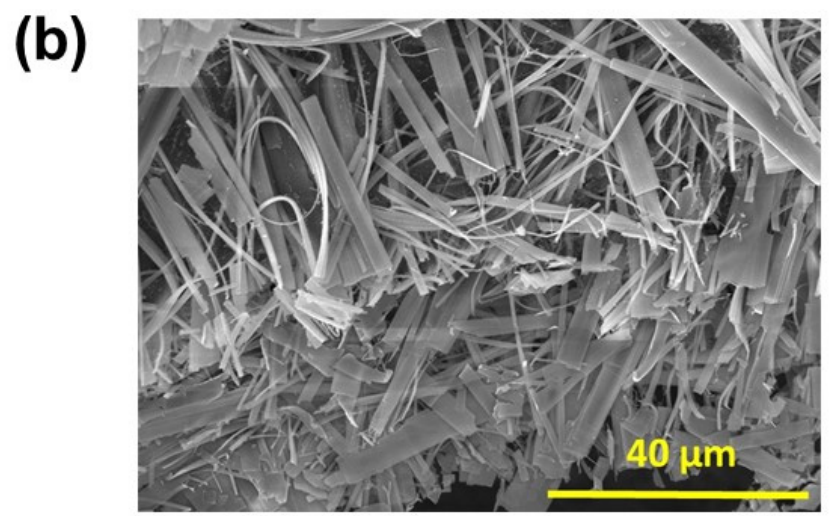

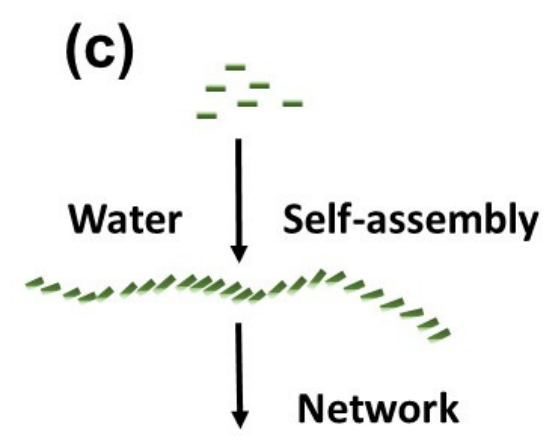

\section{Supramolecular hydrogel}

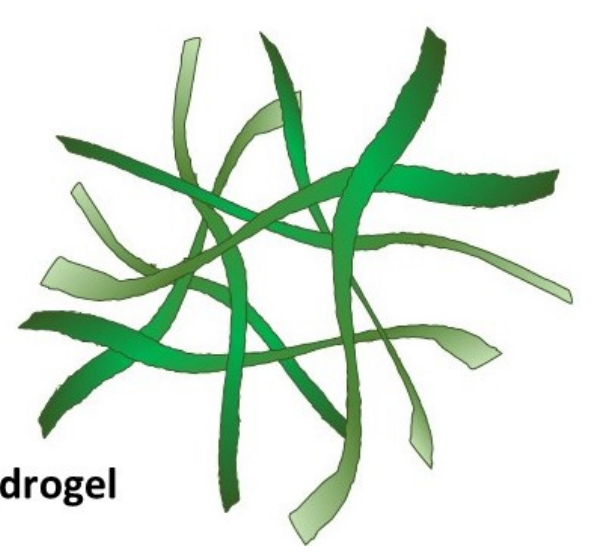

Figure 2. (a) Molecular structure of N-heptyl-D-galactonamide. (b) Hydrogel fibers (cryo-SEM) and (c) mechanism of the supramolecular hydrogel formation.

For studying the cell expression profile, five genes were selected to highlight the differentiation of the cells either in astrocytes, oligodendrocytes, or neurons. Sex Determining Region Y (SRY)-box 8 (Sox8), SRY-box 9 (Sox9), and SRY-box 10 (Sox10) are three genes coding for the three transcription factors Sox8, Sox9, and Sox10 that form the subgroup SoxE of Sox transcription factors. In vivo, they regulate the gene expression in different tissues and at different times of development or adult life [34-37]. In the context of the CNS, Sox9 has a key role in neural stem cell induction and survival and for their differentiation into glial cells, either astrocytes or oligodendrocytes. During embryogenesis, it is expressed by astrocyte precursor cells and at a lower level, by oligodendrocyte precursor cells [37-39]. Then Sox9 continues to be expressed at a high level in mature astrocytes while it stops in mature oligodendrocytes. As a result, Sox9 is often used as a specific marker of mature astrocytes [39-48]. Conversely, the Sox10 transcription factor is expressed at a high level in mature oligodendrocytes and is essential for the myelinization process, while Sox10 expression is turned off in mature astrocytes and early in neuron lineage [37]. Thus Sox10 is generally considered as a marker of oligodendrocytes [38], but it is also expressed by immature glial cells [49]. Sox8 also acts in these processes. Despite a role often redundant with Sox10 and Sox 9 factors and less critical than Sox 9 and Sox10, it is coexpressed with those factors at different stages. Notably, Sox 8 function becomes prominent late in myelinated oligodendrocytes and interacts with Sox10 for myelin maintenance $[34,44,48,50]$.

Two markers of neurons have been selected. Doublecortin (Dcx) is a marker transiently expressed by neuronal precursor cells in vivo [51,52]. It is essential for the normal development of the hippocampus and lamination. It is expressed nearly exclusively in dividing immature neurons and is not expressed by the glial progenitor cells. Thus, it is considered a marker of neurogenesis [53-56]. Neurod1 is a transcription factor acting in the conversion of neural progenitor cells to mature neurons in vivo. It is considered a neuronal differentiation factor. It is highly expressed during the development of neurons in the peripheral and CNS. It enables the survival, migration, and maturation of newborn neurons in the brain during development and adulthood [57,58]. It is also essential for the normal development of the hippocampus [58-60]. It allows the maintenance and repair of 
tissue [61] and it has been shown also that it can be used for reprogramming glial cells to neurons and for reversing glial scar [62].

In this study, the quantitative analysis of the gene expression of these five markers in mouse embryo hippocampi primary cells grown in the four conditions described in Figure 1 was made by qPCR. The results are detailed below.

\section{Material and Methods}

N-Heptyl-D-galactonamide, which can be purchased from Innov'Orga (Reims, France), was synthesized according to the protocol described in the work of Chalard, A. et al. [20].

\subsection{Mice}

Eight-week-old Balb/c inbred mice were used. The mice were housed at a room temperature of $20-24{ }^{\circ} \mathrm{C}$ and a relative humidity of $45-70 \%$ in cages with a minimum area of $180 \mathrm{~cm}^{2}$ and a minimum height of $12 \mathrm{~cm}$. Once the mice reached sexual maturity, they were mated (one male and two females). In the early morning, the mice were checked for the presence of a vaginal plug, a marker of mating in females. Mice with vaginal plugs were considered as pregnant for 0.5 days. After 19 days of pregnancy (E19.5), the mice were sacrificed, and the uterus removed into phosphate-buffered saline (PBS). Embryos were removed from the uteri of pregnant mice on E19.5 with forceps. In total four male embryos were used in this study: one for each group/experiment. The protocols were approved by Erciyes University Animal Ethics Committee, number 16/132.

\subsection{Dissection of Embryonic Hippocampus}

After the whole brain of each embryo was removed, it was collected on a slide and incubated for $2 \mathrm{~min}$ at $-20^{\circ} \mathrm{C}$. The right and left hippocampi were aspirated from 4 different embryos with an individual pipette tip and put into different Eppendorf tubes. For condition 1 aspirated fresh embryonic hippocampi of first embryo used for RNA isolation, $300 \mu \mathrm{L}$ TriPure Isolation Reagent (Roche, Germany) was added to the aspirated hippocampus. For condition 2, 3, and 4 aspirated embryonic hippocampi of other three embryos washed with $1 \mathrm{~mL}$ Hanks' balanced salt (HBS) solution and cultured. The second embryo was used for condition 2: primary cells from the embryonic hippocampus cultured on GalC7 gel for 7 days, the third embryo was used for condition 3: primary cells cultured as neurospheres for 19 days, and the fourth embryo was used for condition 4: cells grown as neurospheres for 12 days, then grown 7 days further on GalC7. Tissue was taken from the tail of each embryo, and DNA was isolated for gender determination (see the "Gender Detection of E19.5 Embryos" section).

\subsection{Gender Detection of E19.5 Embryos}

\section{a. DNA isolation}

Tissue fragments from the embryos were transferred to Eppendorf tubes containing $300 \mu \mathrm{L}$ of lysis buffer (20 mM Tris-HCl PH 8, $100 \mathrm{mM}$ EDTA PH 8, 0.1\% sodium dodecyl sulfate (SDS), distilled water, and proteinase $\mathrm{K} 400 \mu \mathrm{L} / \mathrm{mL}$ ). The samples incubated overnight at $55{ }^{\circ} \mathrm{C}$. After incubation, $100 \mu \mathrm{L}$ of ammonium acetate was added and mixed thoroughly. The samples were centrifuged at $4000 \mathrm{rpm}$ for $20 \mathrm{~min}$. The supernatants were transferred to clean Eppendorf tubes, and $500 \mu \mathrm{L}$ of isopropanol was added and incubated for $5 \mathrm{~min}$ at room temperature. After incubation, centrifugation was performed for $10 \mathrm{~min}$ at $4000 \mathrm{rpm}$, and $1 \mathrm{~mL}$ of $70 \%$ ethanol was added to the pellet that remained after the supernatant was discarded. The samples were again centrifuged at $4000 \mathrm{rpm}$ for $10 \mathrm{~min}$, and the supernatant was discarded. The Eppendorf tubes were incubated with the lids open for $10 \mathrm{~min}$ at room temperature to remove the alcohol from the resulting pellets. After drying, the pellets were dissolved in $100 \mu \mathrm{L}$ of nuclease-free water (NFW) (Qiagen, Germany). The DNA concentration was measured using a Biospec Nano spectrophotometer (Shimadzu, Kyoto, Japan). 


\section{b. Polymerase chain reaction (PCR)}

After DNA isolation, Sry forward (5'TGCACAATTGTCTAGAGAGC3') and reverse (5' ACTGCAGAAGGTTGTACAGT3') and Pax6 forward (5'CTTTCTCCAGAGCCTCAAT3') and reverse ( $5^{\prime}$ GCAACAGGAAGGAGGGGGAGA $\left.3^{\prime}\right)$ primers were used for PCR amplification (Table 1). Five microliters DNA (10 pg-1 $\mu \mathrm{g}$ ), $5 \mu \mathrm{L}$ 10X Taq Buffer, $4 \mu \mathrm{L} 25 \mathrm{mM}$ $\mathrm{MgCl}_{2}, 4 \mu \mathrm{L}$ dNTP mix (2.5 mM each), $0.5 \mu \mathrm{L} 10 \mu \mathrm{M}$ each primer, $0.5 \mu \mathrm{L} 1.25 \mathrm{U}$ Taq DNA Polymerase (Thermo Fisher, Waltham, MA, USA), and water (depending on the reaction volume) were mixed in a $0.2 \mathrm{~mL}$ tube. The samples were incubated in a thermocycler (SensoQuest, Göttingen, Germany) under the following conditions: predenaturation at $95^{\circ} \mathrm{C}$ for $5 \mathrm{~min}, 1 \mathrm{~min}$ of denaturation at $94^{\circ} \mathrm{C}$ for 30 cycles, annealing at $57^{\circ} \mathrm{C}$ for $45 \mathrm{~s}$, extension at $72{ }^{\circ} \mathrm{C}$ for $1 \mathrm{~min}$, and finally $10 \mathrm{~min}$ at $72{ }^{\circ} \mathrm{C}$. The PCR products were run on a $2 \%$ agarose gel containing ethidium bromide. The gel was imaged using a gel imaging system (Bio-Rad, Hercules, CA, USA) and the Image Lab analysis software (Figure 3).

Table 1. Primer sequences used for gender determination.

\begin{tabular}{|c|c|c|c|}
\hline Target Gene & $\begin{array}{c}\text { Primer Sequences } \\
\qquad\left(5^{\prime}-3^{\prime}\right)\end{array}$ & Product Size (bp) & $\begin{array}{c}\text { Primer } \\
\text { Concentration }(\mu \mathrm{M})\end{array}$ \\
\hline Sry & $\begin{array}{c}\text { Forward: } \\
\text { TGCACAATTGTC- } \\
\text { TAGAGAGC } \\
\text { Reverse: } \\
\text { ACTGCAGAAG- } \\
\text { GTTGTACAGT }\end{array}$ & 329 & $10 \mu \mathrm{M}$ \\
\hline Pax6 & $\begin{array}{c}\text { Forward: } \\
\text { CTTTCTCCAGAGC- } \\
\text { CTCAAT } \\
\text { Reverse: } \\
\text { GCAACAGGAAG- } \\
\text { GAGGGGGAGA }\end{array}$ & 150 & $10 \mu \mathrm{M}$ \\
\hline
\end{tabular}

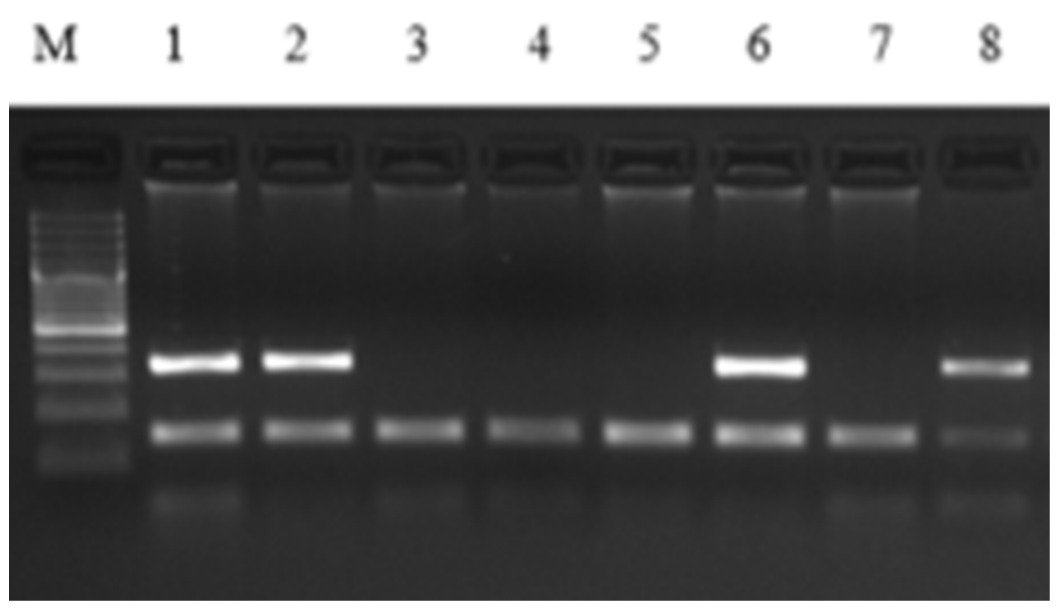

Figure 3. Gender determination gel image. $M$ indicates marker (100-3000 bp). The 1st, 2nd, and 6th embryos were males, and the 3rd, 4th, and 5th embryos were females. The 7 th sample was a positive control female, and the 8th sample was a positive control male.

\subsection{Preparation of the Hydrogel in Culture Plates}

For each sample, $9 \mathrm{mg}$ of GalC7 was weighed and poured into a flask and $2 \mathrm{~mL}$ of ultrapure water (Merck, Kenilworth, NJ, USA) was added. The volume of the flask must be at least five times greater than the volume of water introduced (typically $10 \mathrm{~mL}$, to avoid a too high pressure in the flask when heated). A programmable oven was heated to $115^{\circ} \mathrm{C}$, and the flask was placed in the oven with the lid slightly closed. GalC7 in powder form 
was incubated intermittently in the oven until it dissolved. When the powdered GalC7 was dissolved, the temperature of the oven was reduced to $105^{\circ} \mathrm{C}$, and 24 -well culture plates were placed in the oven. On the outside, distilled water inside of a metal tray (large enough to fit the plate) was put on the incubator. When distilled water boiled, $500 \mu \mathrm{L}$ of GalC7 was pipetted gently but be very quickly to avoid the setting of the gel into the pipette cone.

Before the GalC7 in the plate became a gel, the plate was quickly put on the oven and sandwiched between two empty plates. A steel block was placed on the top of the plates, and the temperature of the oven was slowly decreased from $105^{\circ} \mathrm{C}$ to room temperature (minimum of $90 \mathrm{~min}$ ). Thus, the gel was formed by slow cooling to protect it from thermal shock, providing a more homogeneous gel. When the gel was formed, the plate was moved to a laminar cabinet, where the lid was opened and the water droplets on the well walls were removed with a pipette. Then, $300 \mu \mathrm{L}$ of medium was pipetted very slowly onto the gel and incubated at $37^{\circ} \mathrm{C}$ for $5 \mathrm{~h}$ in an oven containing $5 \% \mathrm{CO}_{2}$. After incubation, the old medium was withdrawn with a pipette, and $300 \mu \mathrm{L}$ of medium was added again and incubated overnight at $37^{\circ} \mathrm{C}$ in an oven containing $5 \% \mathrm{CO}_{2}$. After incubation, the old medium was withdrawn with a pipette, and $300 \mu \mathrm{L}$ of medium was added and incubated again in an oven containing $5 \% \mathrm{CO}_{2}$ at $37^{\circ} \mathrm{C}$ for $5 \mathrm{~h}$. The aim was that the water in the gel was replaced with the medium. The medium was not changed during the 7 days of culture.

\subsection{Primary Cell Culture}

a. Primary cell culture in culture plates coated with poly(HEMA)

The following procedures were performed for primary culture of cells from the hippocampus: Poly(hydroxyethylmethacrylate) (pHEMA) (Sigma, Darmstadt, Germany) was prepared one day before the start of culture. A total of $300 \mathrm{mg}$ pHEMA was dissolved in $10 \mathrm{~mL}$ of $95 \%$ ethanol in a water bath $\left(65^{\circ} \mathrm{C}\right)$ with occasional vortexing. pHEMA $(200 \mu \mathrm{L})$ was pipetted into each well of a 24-well plate in a laminar cabinet. The plate was left in the cabinet overnight with the lid open to allow the alcohol to evaporate. The following day, the right and left hippocampi were aspirated from the embryos of pregnant mice at E19.5 and were taken up in $1 \mathrm{~mL}$ HBS solution. Tissues were resuspended and centrifuged at $1000 \mathrm{rpm}$ for $2 \mathrm{~min}$ at room temperature. Dulbecco's modified Eagle medium/nutrient mixture F-12 (DMEM/F12) (Sigma Germany) was used for the cultivation of cells. Fetal bovine serum (FBS; 10\%) (Sigma, Germany), 1\% penicillin-streptomycin (pen-strep) (Gibco, Life Technologies, Carlsbad, CA, USA), and L-glutamine (200 mM) (Gibco, Life Technologies) were added to the DMEM/F12, and ready-to-use medium was obtained. After centrifugation, the supernatant was discarded, and the cells were resuspended in $1 \mathrm{~mL}$ ready-to-use medium. Each sample was seeded in two pHEMA-coated plates $(500 \mu \mathrm{L}$ per well). The plates were incubated at $37^{\circ} \mathrm{C}$ in an oven containing $5 \% \mathrm{CO}_{2}$. On the 3 rd day of culture, 1X Insulin-Transferrin-Selenium-A (ITS) and 1X B27 supplement were added to each well. Step 7 was repeated on the 7 th day of culture. On the 12 th day of culture, the neurospheres were evenly distributed into two separate Eppendorf tubes using a mouth pipette under an inverted microscope. The neurospheres from one Eppendorf tube was cultured with GalC7 for 7 days, and the others were transferred to a new pHEMA coated plate and cultured for 7 days more.

b. Primary cell culture with GalC7 gel

Aspirated embryonic hippocampal tissues, were washed with HBS and then centrifuged at $1000 \mathrm{rpm}$ for $2 \mathrm{~min}$ at room temperature, and the pellet was resuspended in $250 \mu \mathrm{L}$ of ready-to-use medium. 1X B27 supplement and 1X ITS were added to the samples, and the samples were gently inverted. The resuspended samples were carefully pipetted into wells containing GalC7 gel to not damage the gel. The plate was incubated at 5\% $\mathrm{CO}_{2}$ at $37^{\circ} \mathrm{C}$. Seven days later, the culture was terminated, and RNA was isolated (see method below).

c. Cell culture of neurospheres with the GalC7 gel 
When the cultures were 12 days old, the neurospheres were transferred to Falcon tubes, and $500 \mu \mathrm{L}$ of $0.25 \%$ trypsin-EDTA (Gibco, Life Technologies) was added to the neurospheres for a total volume of $2 \mathrm{~mL}$ and incubated at $37^{\circ} \mathrm{C}$ for $5 \mathrm{~min}$. After the addition of $1 \mathrm{~mL}$ of ready-to-use medium to the Falcon tubes, the tubes were centrifuged at $1000 \mathrm{rpm}$ for $2 \mathrm{~min}$ at room temperature. After the supernatants were discarded, the pellets were resuspended with $250 \mu \mathrm{L}$ of ready-to-use medium. After the addition of $1 \mathrm{X}$ B27 supplement and 1X ITS to the samples, the samples were cultured in wells containing GalC7 gel (Figure 4). The culture was stopped after 7 days, and RNA was isolated.

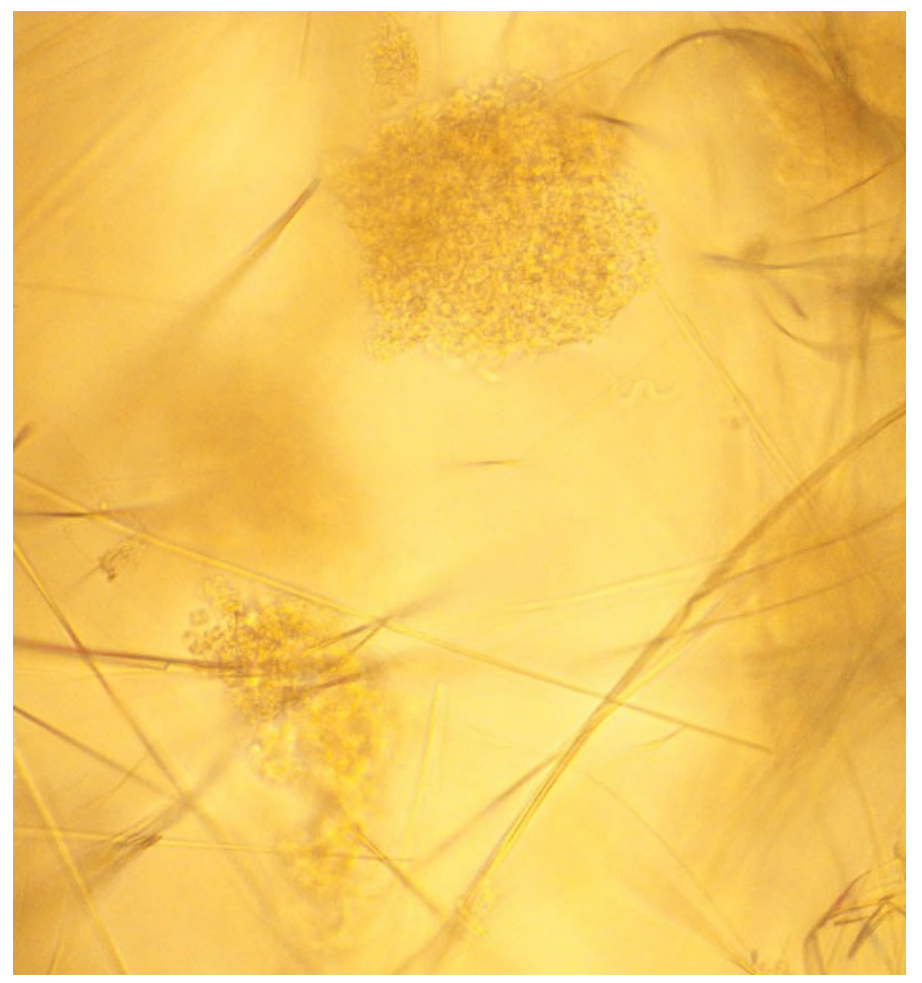

Figure 4. Image of 3D neurosphere culture in GalC7 gel (magnification at $20 \times$ ).

\subsection{RNA Isolation}

RNA was isolated from male embryos identified by PCR.

a. Isolation of RNA from E19.5 embryonic hippocampi

Three hundred microliters TriPure Isolation Reagent (Roche, Mannheim, Germany) was added to hippocampal tissues, and the tissues were homogenized with a syringe. One hundred microliters of chloroform was added, and the samples were vortexed for $15 \mathrm{~s}$. The tubes were centrifuged at $10,000 \mathrm{rpm}$ for $20 \mathrm{~min}$ at $4{ }^{\circ} \mathrm{C}$. After centrifugation, the aqueous phase was transferred to a new Eppendorf tube. Three hundred microliters isopropanol was added to the tube, and the aqueous phase was collected, vortexed well, and stored at $-20{ }^{\circ} \mathrm{C}$ overnight. After incubation, the tubes were centrifuged at 10,000 rpm for $10 \mathrm{~min}$ at $4{ }^{\circ} \mathrm{C}$, and the supernatant was discarded. One milliliter ethanol was added to the pellet for washing, and the tubes were gently inverted a few times. The tubes were centrifuged at $8000 \mathrm{rpm}$ for $5 \mathrm{~min}$ at $4{ }^{\circ} \mathrm{C}$, and the supernatant was discarded. The washing process (Step 7) was repeated, and the supernatant was discarded after centrifugation. The pellet was dissolved in $30 \mu \mathrm{L}$ NFW (Qiagen, Hilden, Germany), and absorbance measurements were performed using a Biospec Nano spectrophotometer (Shimadzu, Kyoto, Japan).

b. Isolation of RNA from primary cells cultured with pHEMA

When the cultures were 19 days old, the contents of the pHEMA-coated plate were transferred to Eppendorf tubes with Pasteur pipettes. At the end of the culture, the following protocol was used for RNA isolation. After the tubes were centrifuged at $1000 \mathrm{rpm}$ 
for $2 \mathrm{~min}$ at room temperature, $1 \mathrm{~mL}$ of TriPure Isolation Reagent (Roche, Germany) and $1 \mu \mathrm{L}(20 \mathrm{ng} / \mathrm{mL})$ of glycogen were added, and the tubes were vortexed thoroughly. Two hundred microliters of chloroform was added to the tubes, and they were vortexed for $15 \mathrm{~s}$. The tubes were centrifuged at $10,000 \mathrm{rpm}$ for $20 \mathrm{~min}$ at $4{ }^{\circ} \mathrm{C}$. After centrifugation, the aqueous phase was transferred to a new Eppendorf tube. Then, $500 \mu \mathrm{L}$ of isopropanol was added to the tube, and the aqueous phase was collected, vortexed well, and stored at $-20{ }^{\circ} \mathrm{C}$ overnight. After incubation, the tubes were centrifuged at 10,000 rpm for $10 \mathrm{~min}$ at $4{ }^{\circ} \mathrm{C}$, and the supernatant was discarded. One milliliter of ethanol was added to the pellet for washing, and the tubes were gently inverted a few times. The tubes were centrifuged at $8000 \mathrm{rpm}$ for $5 \mathrm{~min}$ at $4^{\circ} \mathrm{C}$, and the supernatant was discarded. The washing process was repeated, and the supernatant was discarded after centrifugation. The pellet was dissolved in $30 \mu \mathrm{L}$ of nuclease-free water (Qiagen, Germany), and absorbance measurements were performed using a Biospec Nano spectrophotometer (Shimadzu).

c. Isolation of RNA from primary cells cultured with GalC7 gel

At 7 days of culture, the medium was withdrawn carefully as to avoid damaging the gel. Two hundred microliters of PBS was pipetted onto the gel and withdrawn to remove any non-adherent cells from the gel. The following procedures for RNA isolation were then performed. One milliliter of TriPure Isolation Reagent (Roche, Germany) was added to each well containing GalC7 gel by pipetting to dissolve the gel. TriPure Isolation Reagent and the cell mixture were transferred from the wells to Eppendorf tubes by pipetting. The tubes were thoroughly vortexed, and then $1 \mu \mathrm{L}(20 \mathrm{ng} / \mathrm{mL})$ of glycogen and $200 \mu \mathrm{L}$ of chloroform were added to the Eppendorf tubes, which were vortexed for $15 \mathrm{~s}$. The tubes were centrifuged at $10,000 \mathrm{rpm}$ for $20 \mathrm{~min}$ at $4{ }^{\circ} \mathrm{C}$. After centrifugation, the aqueous phase was transferred to a new Eppendorf tube. Then, $500 \mu \mathrm{L}$ isopropanol was added to the tubes, and the aqueous phase was collected, vortexed well, and stored at $-20{ }^{\circ} \mathrm{C}$ overnight. After incubation, the tubes were centrifuged at $10,000 \mathrm{rpm}$ for $10 \mathrm{~min}$ at $4{ }^{\circ} \mathrm{C}$, and the supernatant was discarded. One milliliter of ethanol was added to the pellet for washing, and the tubes were gently inverted a few times. The tubes were centrifuged at $8000 \mathrm{rpm}$ for $5 \mathrm{~min}$ at $4{ }^{\circ} \mathrm{C}$, and the supernatant was discarded. The washing process was repeated, and the supernatant was discarded after centrifugation. The pellet was dissolved in $30 \mu \mathrm{L}$ NFW (Qiagen, Germany), and absorbance measurements were performed using a Biospec Nano spectrophotometer (Shimadzu).

\subsection{Complementary DNA (cDNA) Synthesis}

The EvoScript cDNA Kit (Roche, Germany) was used to synthesize cDNA from RNA samples. A mixture of $4 \mu \mathrm{L}$ reaction buffer (5X) and $14 \mu \mathrm{L}$ template RNA $(2.5 \mu \mathrm{g} / 20 \mu \mathrm{L})$ was kept on ice for $5 \mathrm{~min}$. At the end of this period, $2 \mu \mathrm{L}$ enzyme mixture was added to each sample, and the samples were incubated for $15 \mathrm{~min}$ at $42{ }^{\circ} \mathrm{C}, 5 \mathrm{~min}$ at $85^{\circ} \mathrm{C}$ and $15 \mathrm{~min}$ at $65^{\circ} \mathrm{C}$ in a thermocycler (SensoQuest) (Table 2). The cDNA samples obtained after incubation were used for preamplification.

Table 2. Conditions for cDNA synthesis.

\begin{tabular}{|c|c|}
\hline Reaction buffer (5X) & $4 \mu \mathrm{L}$ \\
\hline Template RNA $(2.5 \mu \mathrm{g} / 20 \mu \mathrm{L})$ & * \\
\hline NFW & ** \\
\hline \multicolumn{2}{|c|}{ kept on ice for $5 \mathrm{~min}$. } \\
\hline Enzyme mixture & $2 \mu \mathrm{L}$ \\
\hline & \\
\hline
\end{tabular}




\subsection{Preamplification Method}

The Pre-AMP Master Kit (Roche, Germany) was used for preamplification. Primers/ Probes (Integrated DNA Technologies, Belgium) were diluted by 10\%. For preamplification, $5 \mu \mathrm{L}$ of cDNA, $10 \mu \mathrm{L}$ of Preamp master mix, $1.4 \mu \mathrm{L}$ of diluted primers/probes, and nucleasefree water that complete the final volume to $25 \mu \mathrm{L}$ were used. Sample tubes were incubated at Thermal Cycler (SensoQuest) for $1 \mathrm{~min}$ at $95^{\circ} \mathrm{C}$ for $15 \mathrm{~min}$ at $95^{\circ} \mathrm{C}$ for 15 cycles at $4{ }^{\circ} \mathrm{C}$ for $60 \mathrm{~min}$.

\subsection{Measurement of mRNA Expression Levels by qPCR}

To measure mRNA expression levels, a mixture of $10 \mu \mathrm{L}$ of $2 \mathrm{X}$ Probe Master Mix (Roche, Germany), $1 \mu \mathrm{L}$ of primer/probe (Integrated DNA Technologies, Leuven, Belgium), and $4 \mu \mathrm{L}$ of nuclease-free water was pipetted into 96-well plates (Roche, Germany). Five microliters of preamp cDNA (diluted 1/40) was added to each well on the plate. Whole samples were studied in duplicate. The well plates were sealed and placed in a LightCycler $480 \mathrm{II}$ (Roche, Germany) for $10 \mathrm{~min}$ at $95^{\circ} \mathrm{C}, 10 \mathrm{~s}$ at $95^{\circ} \mathrm{C}$ for 50 cycles, $30 \mathrm{~s}$ at $60^{\circ} \mathrm{C}, 1 \mathrm{~s}$ at $72{ }^{\circ} \mathrm{C}$, and $30 \mathrm{~s}$ at $40^{\circ} \mathrm{C}$ for cooling. Beta-actin was used as a housekeeping gene. The data were analyzed using the 2DD Ct method and normalized using the values obtained in the ex vivo conditions "hippocampi 19.5 pc" as the calibrator.

\section{Results and Discussion}

\subsection{Culture and Conditions}

Four conditions for primary hippocampal cells were chosen following schematic presentation (Figure 1). Once steady culture conditions were achieved, total RNA was extracted at different time points (see the "Materials and Methods" section for culture conditions). To extract total RNA from hippocampal cells in culture under different conditions, including GalC7 gel, we introduced modifications to the routine Trizol method. The GalC7 gel is soft and is easily damaged during washing steps. To avoid breaking the gel during the washing steps, we lysed the cells together with the gel. We added TriPure Isolation Reagent to cell-free gel, which was perfectly lysed under these conditions, and we checked its specific absorbance and interference with qPCR. Absorbance measurements were performed by applying an RNA isolation protocol to an empty gel. We observed that the peak of the GalC7 gel (Figure 4) was very similar to the RNA peak we previously observed. Thus, we used an RNA sample with a known Ct value of a housekeeping gene (beta-actin) and mixed the RNA sample with the product isolated from the cell-free GalC7 gel. Then, the Ct value of this mixture was determined, and we found that the beta-actin $\mathrm{Ct}$ value was unchanged. These results demonstrated that GalC7 gel did not inhibit PCR. After this experiment, total RNA was isolated from GalC7 gel containing embryonic hippocampal neurons (see profile of RNA in Figure 4).

\subsection{Gene Expression Studies with $q P C R$}

In Figure 5 is reported the transcript expression analyzed from cells grown in the following conditions: (condition 1): cells obtained from fresh embryonic hippocampi E19.5 pc.; (condition 2): primary cells from the embryonic hippocampus cultured on GalC7 gel for 7 days, (condition 3): primary cells cultured as neurospheres for 19 days, and (condition 4): cells grown as neurospheres for 12 days, then grown 7 days further on GalC7. 

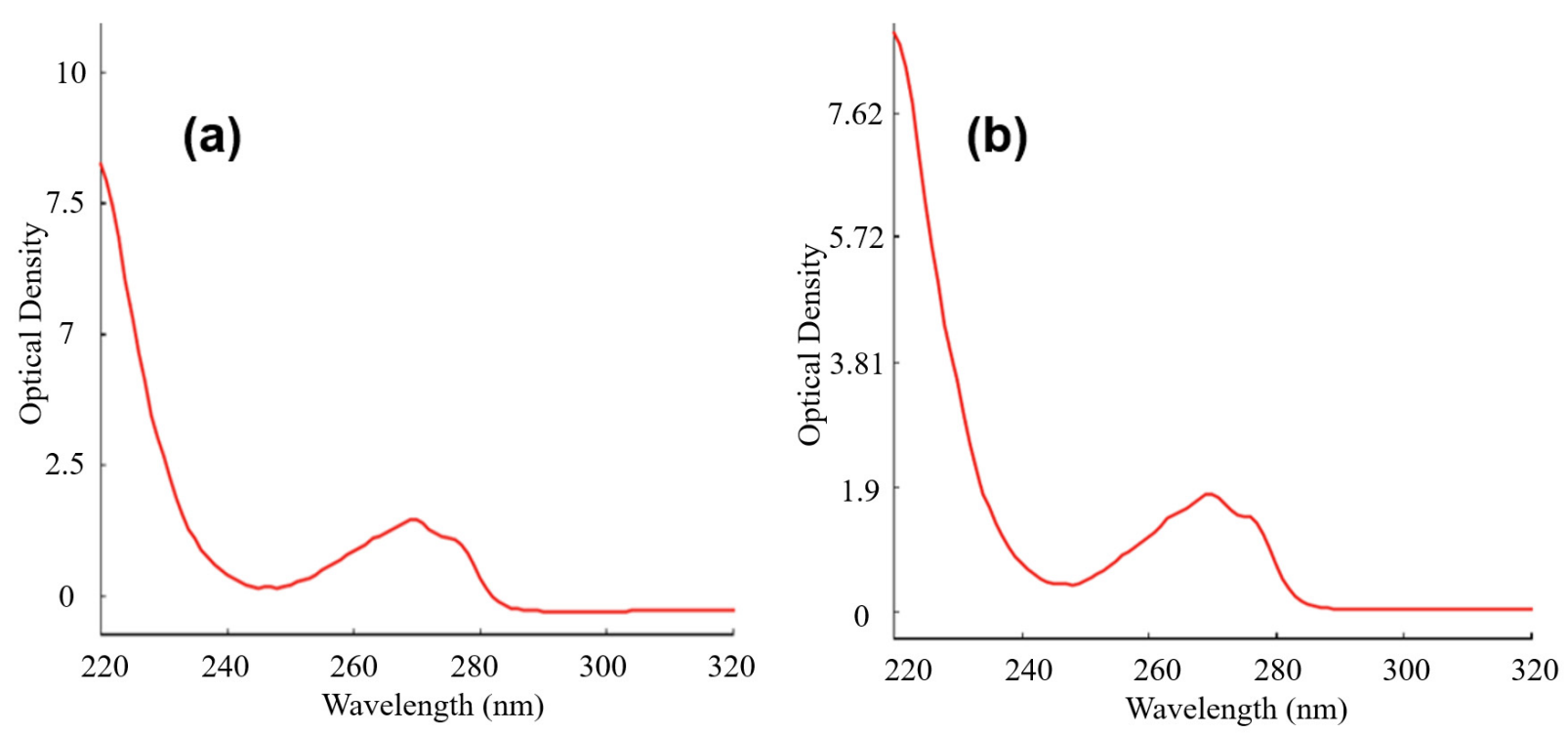

Figure 5. The absorbance value of GalC7 gel without (a) and with (b) cultured neuronal cells.

The transcript levels of Sox8, Sox9, and Sox10 were found to be much higher in cells cultured on GalC7 gel after 7 days than in cells from the other groups (Figure 5, Sox8, Sox9, and Sox10). Based on the results, it can be concluded that the culture on GalC7 hydrogel directs the fate of the hippocampal primary cells predominantly towards glial cells, either oligodendrocytes and/or astrocytes, compared with in vivo (condition 1). When the cells are grown as neurospheres for a longer time (19 days) (condition 3) Sox 8 and Sox 10 are not expressed anymore, which show that astrocytes would be the main population of cells in this condition. Growing the neurospheres during only 12 days and then for 7 days more in GalC7 hydrogel does not change this profile. It shows that in the case of the glial cells, the fate of the cells and the resulting transcripts have been determined at an early stage of the cell culture by the conditions on which the cells are grown and cannot be changed by adding GalC7.

Otherwise, Dcx and Neurod1 transcript levels were much higher in fresh embryonic hippocampi than in other conditions (Figure 6, Dcx and Neurod1). It is consistent with the fact that a high level of neurogenesis and neuronal differentiation is expected in hippocampi. Conversely, in in vitro conditions, cells grown as neurospheres for 19 days did not express these markers. Otherwise, cells grown in GalC7 hydrogels can express at some level the two markers at day 7, around $1 / 4$ the one observed in ex vivo for Neurod1. Even if the transcription level of $D c x$ remains lower than in the hippocampi, the presence of $D c x$ transcripts after 7 days of culture on GalC7 gel suggests the presence of neurogenesis in these conditions. The cell culture was not performed longer on GalC7 because the gel was consumed by the cells within 7-10 days, thus gene expression on a longer time could not be quantified. However, from the results of condition 4 (neurospheres for 12 days, then GalC7 for 7 days), it is observed that the level of Neurod1 was better maintained when the neurospheres are grown for 7 extra days on GalC7 gel instead of being grown in the neurospheres culture condition only (condition 3, 19 days). The presence of a relatively high level of Neurod1 transcripts after 7 days of culture on GalC7 gel suggests the differentiation of some cells into neurons in condition 2 and in condition 4. It is worth noting that these results were obtained without the addition of any extra factors, the GalC7 hydrogel being the only extra molecule added to the culture conditions. 


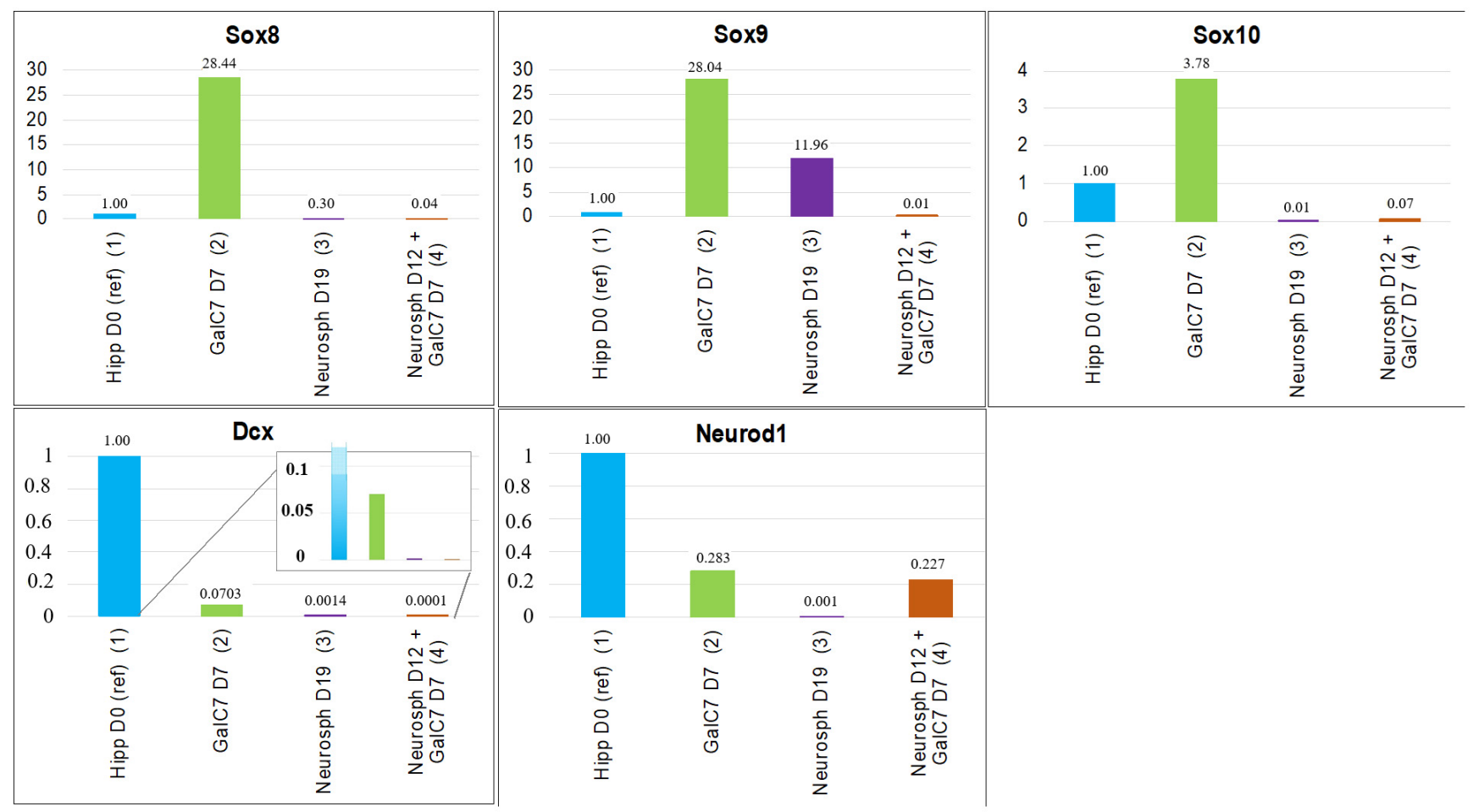

Figure 6. Transcript analysis qPCR results. (1) Hippocampi at day 19.5 pc. (2) Cells cultured on GalC7 gel for 7 days (D7), (3) cells cultured as neurospheres with pHEMA coatings for 19 days (D19), and (4) cells cultured as neurospheres with pHEMA coatings for 12 days (D12) then on GalC7 gel for 7 days (D7).

The results raise the question why this hydrogel would favor glial cells and possibly oligodendrocytes, and to a lesser extent, neurons. N-heptyl-D-galactonamide is an acyclic galactose derivative, in which the anomeric carbon of the galactose is oxidized and linked with an amide bond to a fatty chain. It means that N-heptyl-D-galactonamide fibers display molecular patterns, a polyol configuration, that could mimic at some points galactolipids. Galactocerebrosides (GalC) are glycolipids produced by oligodendrocytes at a high level. They are also highly specific of those cells so that immunolabeling targeting galactocerebrosides (anti-GalC) is used for the identification and separation of oligodendrocytes [63].

These glycolipids play an important role in oligodendrocyte differentiation, maturation, myelinization, and oligodendrocyte-axon interaction [64,65]. Up to now, preliminary studies on this scaffold [37] had focused on the effect of the microscopic architecture and mechanical properties on the nervous cell survival and early differentiation markers. It is possible also that the chemical structure of the molecule might have influenced the fate of the cells. The high level of Sox10 factor might be due either to the early stage of the culture (7 days), because both Sox8, Sox9, and Sox10 are expressed in immature glial cells or might highlight an effect of $\mathrm{GalC7}$ favoring oligodendrocytes.

The results tend to indicate also that the GalC7 hydrogel is a favorable in vitro condition for neurogenesis and the differentiation of the primary cells into neurons. The fibrillar network provides mechanical signals and topological clues that are very different compared with the neurospheres culture conditions. In the case of GalC7, the fibrillar network is made of coarse heterogeneous ribbons, some of them being very large, at least the size of a cell. The electronic microscopy (Figure 2) of these fibers suggest that they have nanometric grooves along the fibers, that may have a strong impact in the development of cell projections, especially neurites, which are known to be mechanosensitive and sensitive to topography. It might explain the higher expression of Neurod1 transcript when neurospheres at day 12 are contacted secondary during 7 days with GalC7 (condition 4, 19 days), compared with neurospheres only condition (condition 3, 19 days). These strong structural 
and biochemical differences between the GalC7 hydrogel and the neurospheres conditions may explain the difference of expression of the five markers studied.

As a limitation of this study, we can mention the lack of confirmation of the results at the protein level, considering the experimental difficulties related to the management of this novel hydrogel. Immunocytochemical staining is a very delicate step to do in the case of cells cultured in the supramolecular GalC7 hydrogel. The hydrogel is very soft but also very fragile and is easily removed by the successive steps of the procedure. Since it is not a polymer, there are not any covalent links between molecules. At the end of the culture, if the cells are not embedded in a transparent polymer network before staining, such as polyacrylamide, all the cells will be washed out and they will not be observed. The embedding in polyacrylamide has been performed in a previous publication [20] and requires specific equipment (specific vials, inert atmosphere). For this reason, it cannot be performed routinely. We are currently working on an embedding method that can be implemented more easily.

\section{Conclusions}

This study shows that functional hippocampal cells from mouse embryos (E19.5) can be maintained ex vivo for several days on a supramolecular low molecular weight hydrogel based on a single small molecule, N-heptyl-D-galactonamide (GalC7). New robust conditions have been found, which allow one to reveal different cell characters maintained in culture conditions. It was possible to perform high-quality RNA isolation from GalC7 cultured cells, which opens possibilities to do investigation on transcriptomes via RNA sequencing methods to reveal the differences in transcripts of genes or gene expression differences between different tissues. Embryonic hippocampal cells cultured on GalC7 gel had a high level of expression of the transcription factors Sox8, Sox9, and Sox10. The high level of Sox10 marker tended to show a higher development of oligodendrocytes. The GalC7 hydrogel is also interesting for neuron growth. The level of expression of Neurod1, a marker of neuronal differentiation, has an interesting level for cells grown for 7 days on GalC7 and in neurospheres that have been grown secondary in GalC7 hydrogels. This level was around $1 / 4$ of the level observed in fresh hippocampi, highlighting neuronal differentiation in these conditions. It has been shown that small molecules, but also grooves can help the reprogramming of somatic cells $[36,66]$. The low molecular weight supramolecular hydrogel GalC7, acting as a new molecule and scaffold, provides both chemical and physical cues that deserves to be explored further. They provide conditions that are not obtained with any other polymer scaffolds (natural or synthetic) or with scaffoldfree culture conditions. Detailed analysis of gene expression also gives a very useful quantitative insight of the cell differentiation distribution on these hydrogels compared to conditions studied in other works. They can be quite easily analyzed because the gel can be easily dissolved. Several other directions, such as changing slightly the molecular structure or the architecture of the hydrogel, notably the carbohydrate head, studying its metabolization, its use for cell induction, or studying the combination with other neuronal factors, would be interesting to explore in further studies.

Author Contributions: Conceptualization, A.B., Y.Ö. and M.R.; methodology K.K.B.; software K.K.B., A.B.; validation K.K.B.; formal analysis A.B.; investigation K.K.B., Z.Y. and E.M.; resources J.F., M.R. and Y.Ö.; data curation, K.K.B. and J.F.; writing-original draft preparation, K.K.B., J.F. and M.R.; writing-review and editing A.B, J.F. and M.R., visualization, K.K.B., J.F. and A.B.; supervision, M.R.; project administration, K.K.B. and M.R.; funding acquisition, J.F. and M.R. All authors have read and agreed to the published version of the manuscript.

Funding: This work is supported by the grant 2019-2020 of La Fondation Nestlé France to Minoo Rassoulzadegan, The Scientific Research Projects Unit at Erciyes University, by the French National Research Agency (grant NANR-15-CE07-0007-01). The European Union is also acknowledged for its financial support for equipment (FEDER-35477: "Nano-objets pour la biotechnologie"). 
Institutional Review Board Statement: The study was conducted according to the guidelines of the Declaration of Helsinki and approved by the Ethics Committee of Erciyes University (protocol code 16/132 and date of approval 16/11/2016).

Informed Consent Statement: Not applicable.

Data Availability Statement: Data is available on demand to the corresponding author.

Acknowledgments: Not applicable.

Conflicts of Interest: The authors declare no conflict of interest.

$\begin{array}{ll}\text { Abbreviations } \\ \text { CNS } & \text { Central nervous system } \\ \text { Dcx } & \text { Doublecortin } \\ \text { DMEM/F12 } & \text { Dulbecco's modified Eagle medium/nutrient mixture F-12 } \\ \text { ECM } & \text { Extracellular matrix } \\ \text { GalC } & \text { Galactocerebrosides } \\ \text { GalC7 } & \text { N-heptyl-D-galactonamide } \\ \text { HBS } & \text { Hanks' balanced salt } \\ \text { hNSC } & \text { Human neural stem cell } \\ \text { ITS } & \text { Insulin-Transferrin-Selenium-A } \\ \text { NFW } & \text { Nuclease-free water } \\ \text { PBS } & \text { Phosphate-buffered saline } \\ \text { pHEMA } & \text { Poly(hydroxyethylmethacrylate) } \\ \text { SAFIN } & \text { Self-assembling fibrillar network } \\ \text { SDS } & \text { Sodium dodecyl sulfate } \\ \text { Sox10 } & \text { SRY-box 10 } \\ \text { Sox8 } & \text { SRY-box 8 } \\ \text { Sox9 } & \text { SRY-box 9 } \\ \text { SRY } & \text { Sex Determining Region Y }\end{array}$

\section{References}

1. Zhuang, P.; Sun, A.X.; An, J.; Chua, C.K.; Chew, S.Y. 3D neural tissue models: From spheroids to bioprinting. Biomaterials 2018, 154, 113-133. [CrossRef] [PubMed]

2. Mahumane, G.D.; Kumar, P.; du Toit, L.C.; Choonara, Y.E.; Pillay, V. 3D scaffolds for brain tissue regeneration: Architectural challenges. Biomater. Sci. 2018, 6, 2812-2837. [CrossRef] [PubMed]

3. Centeno, E.G.; Cimarosti, H.; Bithell, A. 2D versus 3D human induced pluripotent stem cell-derived cultures for neurodegenerative disease modelling. Mol. Neurodegener. 2018, 13, 1-15. [CrossRef] [PubMed]

4. Hong, Y.J.; Do, J.T. Neural lineage differentiation from pluripotent stem cells to mimic human brain tissues. Front. Bioeng. Biotechnol. 2019, 7, 400. [CrossRef]

5. Marton, R.M.; Miura, Y.; Sloan, S.A.; Li, Q.; Revah, O.; Levy, R.J.; Huguenard, J.R.; Pasca, S.P. Differentiation and maturation of oligodendrocytes in human three-dimensional neural cultures. Nat. Neurosci. 2019, 22, 484-491. [CrossRef]

6. Pastrana, E.; Silva-Vargas, V.; Doetsch, F. Eyes wide open: A critical review of sphere-formation as an assay for stem cells. Cell Stem Cell 2011, 8, 486-498. [CrossRef]

7. Lancaster, M.A.; Renner, M.; Martin, C.-A.; Wenzel, D.; Bicknell, L.S.; Hurles, M.E.; Homfray, T.; Penninger, J.M.; Jackson, A.P.; Knoblich, J.A. Cerebral organoids model human brain development and microcephaly. Nature 2013, 501, 373-379. [CrossRef]

8. Oliveira, B.; Yahya, A.Ç.; Novarino, G. Modeling cell-cell interactions in the brain using cerebral organoids. Brain Res. 2019, 1724, 146458. [CrossRef]

9. Sood, D.; Cairns, D.M.; Dabbi, J.M.; Ramakrishnan, C.; Deisseroth, K.; Black, L.D.; Santaniello, S.; Kaplan, D.L. Functional maturation of human neural stem cells in a 3D bioengineered brain model enriched with fetal brain-derived matrix. Sci. Rep. 2019, 9, 1-15.

10. Zychowicz, M.; Pietrucha, K.; Podobinska, M.; Kowalska-Wlodarczyk, M.; Lenart, J.; Augustyniak, J.; Buzanska, L. The collagen scaffold supports hiPSC-derived NSC growth and restricts hiPSC. Front. Biosci. (Sch. Ed.) 2019, 11, $105-121$.

11. Salaris, F.; Colosi, C.; Brighi, C.; Soloperto, A.; de Turris, V.; Benedetti, M.C.; Ghirga, S.; Rosito, M.; Di Angelantonio, S.; Rosa, A. 3D bioprinted human cortical neural constructs derived from induced pluripotent stem cells. J. Clin. Med. 2019, 8, 1595. [CrossRef]

12. Gonçalves-Pimentel, C.; Moreno, G.M.M.; Trindade, B.S.; Isaac, A.R.; Rodrigues, C.G.; Savariradjane, M.; de Albuquerque, A.V.; de Andrade Aguiar, J.L.; da Silveira Andrade-da, B.L. Cellulose exopolysaccharide from sugarcane molasses as a suitable substrate for 2D and 3D neuron and astrocyte primary cultures. J. Mater. Sci. Mater. Med. 2018, 29, 1-12. [CrossRef] 
13. Moxon, S.R.; Corbett, N.J.; Fisher, K.; Potjewyd, G.; Domingos, M.; Hooper, N.M. Blended alginate/collagen hydrogels promote neurogenesis and neuronal maturation. Mater. Sci. Eng. C 2019, 104, 109904. [CrossRef]

14. Palazzolo, G.; Broguiere, N.; Cenciarelli, O.; Dermutz, H.; Zenobi-Wong, M. Ultrasoft alginate hydrogels support long-term three-dimensional functional neuronal networks. Tissue Eng. Part A 2015, 21, 2177-2185. [CrossRef] [PubMed]

15. Accardo, A.; Blatché, M.-C.; Courson, R.; Loubinoux, I.; Vieu, C.; Malaquin, L. Direct laser fabrication of free-standing PEGDAhydrogel scaffolds for neuronal cell growth. Mater. Today 2018, 21, 315-316. [CrossRef]

16. Haring, A.P.; Thompson, E.G.; Tong, Y.; Laheri, S.; Cesewski, E.; Sontheimer, H.; Johnson, B.N. Process-and bio-inspired hydrogels for 3D bioprinting of soft free-standing neural and glial tissues. Biofabrication 2019, 11, 025009. [CrossRef]

17. Berns, E.J.; Sur, S.; Pan, L.; Goldberger, J.E.; Suresh, S.; Zhang, S.; Kessler, J.A.; Stupp, S.I. Aligned neurite outgrowth and directed cell migration in self-assembled monodomain gels. Biomaterials 2014, 35, 185-195. [CrossRef] [PubMed]

18. Skilling, K.J.; Citossi, F.; Bradshaw, T.D.; Ashford, M.; Kellam, B.; Marlow, M. Insights into low molecular mass organic gelators: A focus on drug delivery and tissue engineering applications. Soft Matter 2014, 10, 237-256. [CrossRef]

19. Du, X.; Zhou, J.; Shi, J.; Xu, B. Supramolecular hydrogelators and hydrogels: From soft matter to molecular biomaterials. Chem. Rev. 2015, 115, 13165-13307. [CrossRef] [PubMed]

20. Chalard, A.; Vaysse, L.; Joseph, P.; Malaquin, L.; Souleille, S.; Lonetti, B.; Sol, J.-C.; Loubinoux, I.; Fitremann, J. Simple synthetic molecular hydrogels from self-assembling alkylgalactonamides as scaffold for 3D neuronal cell growth. ACS Appl. Mater. Interfaces 2018, 10, 17004-17017. [CrossRef] [PubMed]

21. Latxague, L.; Ramin, M.A.; Appavoo, A.; Berto, P.; Maisani, M.; Ehret, C.; Chassande, O.; Barthélémy, P. Control of stemcell behavior by fine tuning the supramolecular assemblies of low-molecular-weight gelators. Angew. Chem. 2015, 127, 4600-4604. [CrossRef]

22. Moore, A.N.; Silva, T.L.L.; Carrejo, N.C.; Marmolejo, C.A.O.; Li, I.-C.; Hartgerink, J.D. Nanofibrous peptide hydrogel elicits angiogenesis and neurogenesis without drugs, proteins, or cells. Biomaterials 2018, 161, 154-163. [CrossRef] [PubMed]

23. Ji, W.; Álvarez, Z.; Edelbrock, A.N.; Sato, K.; Stupp, S.I. Bioactive nanofibers induce neural transdifferentiation of human bone marrow mesenchymal stem cells. Acs Appl. Mater. Interfaces 2018, 10, 41046-41055. [CrossRef]

24. Edelbrock, A.N.; Àlvarez, Z.; Simkin, D.; Fyrner, T.; Chin, S.M.; Sato, K.; Kiskinis, E.; Stupp, S.I. Supramolecular nanostructure activates TrkB receptor signaling of neuronal cells by mimicking brain-derived neurotrophic factor. Nano Lett. 2018, 18, 6237-6247. [CrossRef] [PubMed]

25. Frick, C.; Müller, M.; Wank, U.; Tropitzsch, A.; Kramer, B.; Senn, P.; Rask-Andersen, H.; Wiesmüller, K.-H.; Löwenheim, H. Biofunctionalized peptide-based hydrogels provide permissive scaffolds to attract neurite outgrowth from spiral ganglion neurons. Colloids Surf. B Biointerfaces 2017, 149, 105-114. [CrossRef]

26. Martin, A.D.; Chua, S.W.; Au, C.G.; Stefen, H.; Przybyla, M.; Lin, Y.; Bertz, J.; Thordarson, P.; Fath, T.; Ke, Y.D. Peptide nanofiber substrates for long-term culturing of primary neurons. ACS Appl. Mater. Interfaces 2018, 10, 25127-25134. [CrossRef]

27. Kim, H.N.; Choi, N. Consideration of the Mechanical Properties of Hydrogels for Brain Tissue Engineering and Brain-on-a-chip. BioChip J. 2019, 13, 8-19. [CrossRef]

28. Koser, D.E.; Thompson, A.J.; Foster, S.K.; Dwivedy, A.; Pillai, E.K.; Sheridan, G.K.; Svoboda, H.; Viana, M.; da F Costa, L.; Guck, J. Mechanosensing is critical for axon growth in the developing brain. Nat. Neurosci. 2016, 19, 1592-1598. [CrossRef] [PubMed]

29. Zheng, H.; Yoshitomi, T.; Yoshimoto, K. Analysis of chirality effects on stem cell fate using three-dimensional fibrous peptide hydrogels. ACS Appl. Bio Mater. 2018, 1, 538-543. [CrossRef]

30. Liu, G.F.; Zhang, D.; Feng, C.L. Control of three-dimensional cell adhesion by the chirality of nanofibers in hydrogels. Angew. Chem. Int. Ed. 2014, 53, 7789-7793. [CrossRef] [PubMed]

31. Franze, K.; Gerdelmann, J.; Weick, M.; Betz, T.; Pawlizak, S.; Lakadamyali, M.; Bayer, J.; Rillich, K.; Gögler, M.; Lu, Y.-B. Neurite branch retraction is caused by a threshold-dependent mechanical impact. Biophys. J. 2009, 97, 1883-1890. [CrossRef]

32. Chalard, A.; Mauduit, M.; Souleille, S.; Joseph, P.; Malaquin, L.; Fitremann, J. 3D printing of a biocompatible low molecular weight supramolecular hydrogel by dimethylsulfoxide water solvent exchange. Addit. Manuf. 2020, 33, 101162. [CrossRef]

33. Chalard, A.; Joseph, P.; Souleille, S.; Lonetti, B.; Saffon-Merceron, N.; Loubinoux, I.; Vaysse, L.; Malaquin, L.; Fitremann, J. Wet spinning and radial self-assembly of a carbohydrate low molecular weight gelator into well organized hydrogel filaments. Nanoscale 2019, 11, 15043-15056. [CrossRef] [PubMed]

34. Turnescu, T.; Arter, J.; Reiprich, S.; Tamm, E.R.; Waisman, A.; Wegner, M. Sox8 and Sox10 jointly maintain myelin gene expression in oligodendrocytes. Glia 2018, 66, 279-294. [CrossRef]

35. Singh, A.; Harada, S.; Mishina, Y. Downstream genes of Sox8 that would affect adult male fertility. Sex. Dev. 2009, 3, 16-25. [CrossRef] [PubMed]

36. Kordes, U.; Cheng, Y.-C.; Scotting, P.J. Sox group E gene expression distinguishes different types and maturational stages of glial cells in developing chick and mouse. Dev. Brain Res. 2005, 157, 209-213. [CrossRef] [PubMed]

37. Weider, M.; Wegner, M. SoxE factors: Transcriptional regulators of neural differentiation and nervous system development. In Proceedings of the Semin. Semin. Cell Dev. Biol. 2017, 63, 35-42. [CrossRef]

38. Wittstatt, J.; Reiprich, S.; Küspert, M. Crazy little thing called Sox-new insights in oligodendroglial Sox protein function. Int. J. Mol. Sci. 2019, 20, 2713. [CrossRef]

39. Sun, W.; Cornwell, A.; Li, J.; Peng, S.; Osorio, M.J.; Aalling, N.; Wang, S.; Benraiss, A.; Lou, N.; Goldman, S.A. SOX9 is an astrocyte-specific nuclear marker in the adult brain outside the neurogenic regions. J. Neurosci. 2017, 37, 4493-4507. [CrossRef] 
40. Pompolo, S.; Harley, V. Localisation of the SRY-related HMG box protein, SOX9, in rodent brain. Brain Res. 2001, 906, 143-148. [CrossRef]

41. Lovatt, D.; Sonnewald, U.; Waagepetersen, H.S.; Schousboe, A.; He, W.; Lin, J.H.-C.; Han, X.; Takano, T.; Wang, S.; Sim, F.J. The transcriptome and metabolic gene signature of protoplasmic astrocytes in the adult murine cortex. J. Neurosci. 2007, 27, 12255-12266. [CrossRef] [PubMed]

42. Barnabé-Heider, F.; Göritz, C.; Sabelström, H.; Takebayashi, H.; Pfrieger, F.W.; Meletis, K.; Frisén, J. Origin of new glial cells in intact and injured adult spinal cord. Cell Stem Cell 2010, 7, 470-482. [CrossRef] [PubMed]

43. Molofsky, A.V.; Glasgow, S.M.; Chaboub, L.S.; Tsai, H.H.; Murnen, A.T.; Kelley, K.W.; Fancy, S.P.; Yuen, T.J.; Madireddy, L.; Baranzini, S. Expression profiling of Aldh111-precursors in the developing spinal cord reveals glial lineage-specific genes and direct Sox9-Nfe211 interactions. Glia 2013, 61, 1518-1532. [CrossRef] [PubMed]

44. Zhang, Y.; Chen, K.; Sloan, S.A.; Bennett, M.L.; Scholze, A.R.; O’Keeffe, S.; Phatnani, H.P.; Guarnieri, P.; Caneda, C.; Ruderisch, N. An RNA-sequencing transcriptome and splicing database of glia, neurons, and vascular cells of the cerebral cortex. J. Neurosci. 2014, 34, 11929-11947. [CrossRef]

45. Farmer, W.T.; Abrahamsson, T.; Chierzi, S.; Lui, C.; Zaelzer, C.; Jones, E.V.; Bally, B.P.; Chen, G.G.; Théroux, J.-F.; Peng, J. Neurons diversify astrocytes in the adult brain through sonic hedgehog signaling. Science 2016, 351, 849-854. [CrossRef]

46. Nagao, M.; Ogata, T.; Sawada, Y.; Gotoh, Y. Zbtb20 promotes astrocytogenesis during neocortical development. Nat. Commun. 2016, 7, 1-14. [CrossRef]

47. Zhang, Y.; Sloan, S.A.; Clarke, L.E.; Caneda, C.; Plaza, C.A.; Blumenthal, P.D.; Vogel, H.; Steinberg, G.K.; Edwards, M.S.; Li, G. Purification and characterization of progenitor and mature human astrocytes reveals transcriptional and functional differences with mouse. Neuron 2016, 89, 37-53. [CrossRef]

48. Azar, S.; Leventoux, N.; Ripoll, C.; Rigau, V.; Gozé, C.; Lorcy, F.; Bauchet, L.; Duffau, H.; Guichet, P.; Rothhut, B. Cellular and molecular characterization of IDH1-mutated diffuse low grade gliomas reveals tumor heterogeneity and absence of EGFR/PDGFR $\alpha$ activation. Glia 2018, 66, 239-255. [CrossRef]

49. Souza, D.G.; Bellaver, B.; Terra, S.R.; Guma, F.C.R.; Souza, D.O.; Quincozes-Santos, A. In vitro adult astrocytes are derived from mature cells and reproduce in vivo redox profile. J. Cell. Biochem. 2017, 118, 3111-3118. [CrossRef]

50. Stolt, C.C.; Lommes, P.; Friedrich, R.P.; Wegner, M. Transcription factors Sox8 and Sox10 perform non-equivalent roles during oligodendrocyte development despite functional redundancy. Development 2004, 131, 2349-2358. [CrossRef]

51. Brown, J.P.; Couillard-Després, S.; Cooper-Kuhn, C.M.; Winkler, J.; Aigner, L.; Kuhn, H.G. Transient expression of doublecortin during adult neurogenesis. J. Comp. Neurol. 2003, 467, 1-10. [CrossRef]

52. Couillard-Despres, S.; Winner, B.; Schaubeck, S.; Aigner, R.; Vroemen, M.; Weidner, N.; Bogdahn, U.; Winkler, J.; Kuhn, H.G.; Aigner, L. Doublecortin expression levels in adult brain reflect neurogenesis. Eur. J. Neurosci. 2005, 21, 1-14. [CrossRef]

53. Gleeson, J.G.; Lin, P.T.; Flanagan, L.A.; Walsh, C.A. Doublecortin is a microtubule-associated protein and is expressed widely by migrating neurons. Neuron 1999, 23, 257-271. [CrossRef]

54. Klempin, F.; Kronenberg, G.; Cheung, G.; Kettenmann, H.; Kempermann, G. Properties of doublecortin-(DCX)-expressing cells in the piriform cortex compared to the neurogenic dentate gyrus of adult mice. PLoS ONE 2011, 6, e25760. [CrossRef]

55. Corbo, J.C.; Deuel, T.A.; Long, J.M.; LaPorte, P.; Tsai, E.; Wynshaw-Boris, A.; Walsh, C.A. Doublecortin is required in mice for lamination of the hippocampus but not the neocortex. J. Neurosci. 2002, 22, 7548-7557. [CrossRef]

56. Moreno-Jiménez, E.P.; Flor-García, M.; Terreros-Roncal, J.; Rábano, A.; Cafini, F.; Pallas-Bazarra, N.; Ávila, J.; Llorens-Martín, M. Adult hippocampal neurogenesis is abundant in neurologically healthy subjects and drops sharply in patients with Alzheimer's disease. Nat. Med. 2019, 25, 554-560. [CrossRef]

57. Aprea, J.; Nonaka-Kinoshita, M.; Calegari, F. Generation and characterization of Neurod1-CreERT2 mouse lines for the study of embryonic and adult neurogenesis. Genesis 2014, 52, 870-878. [CrossRef] [PubMed]

58. Chae, J.H.; Stein, G.H.; Lee, J.E. NeuroD: The predicted and the surprising. Mol. Cells 2004, 18, $271-288$.

59. Miyata, T.; Maeda, T.; Lee, J.E. NeuroD is required for differentiation of the granule cells in the cerebellum and hippocampus. Genes Dev. 1999, 13, 1647-1652. [CrossRef] [PubMed]

60. Roybon, L.; Hjalt, T.; Stott, S.; Guillemot, F.; Li, J.-Y.; Brundin, P. Neurogenin2 directs granule neuroblast production and amplification while NeuroD1 specifies neuronal fate during hippocampal neurogenesis. PLoS ONE 2009, 4, e4779. [CrossRef] [PubMed]

61. Lee, J.K.; Cho, J.H.; Hwang, W.S.; Lee, Y.D.; Reu, D.S.; Suh-Kim, H. Expression of neuroD/BETA2 in mitotic and postmitotic neuronal cells during the development of nervous system. Dev. Dyn. 2000, 217, 361-367. [CrossRef]

62. Liu, M.-H.; Li, W.; Zheng, J.-J.; Xu, Y.-G.; He, Q.; Chen, G. Differential neuronal reprogramming induced by NeuroD1 from astrocytes in grey matter versus white matter. Neural Regen. Res. 2020, 15, 342. [CrossRef] [PubMed]

63. Matsubayashi, Y.; Iwai, L.; Toda, T.; Lu, Q.R.; Kawasaki, H. Immunostaining for oligodendrocyte-specific galactosphingolipids in fixed brain sections using the cholesterol-selective detergent digitonin. J. Neurosci. Methods 2009, 178, 87-98. [CrossRef]

64. Marcus, J.; Popko, B. Galactolipids are molecular determinants of myelin development and axo-glial organization. Biochim. Biophys. Acta 2002, 1573, 406-413. [CrossRef]

65. Ozgen, H.; Baron, W.; Hoekstra, D.; Kahya, N. Oligodendroglial membrane dynamics in relation to myelin biogenesis. Cell Mol. Life Sci. 2016, 73, 3291-3310. [CrossRef] [PubMed]

66. Vignoles, R.; Lentini, C.; d'Orange, M.; Heinrich, C. Direct lineage reprogramming for brain repair: Breakthroughs and challenges. Trends Mol. Med. 2019, 25, 897-914. [CrossRef] [PubMed] 